\title{
Microbes for Electricity Production and Light Emission- An Eco-Friendly Technology
}

Navpreet Kaur Walia ${ }^{1}$, Brijdeep Sing ${ }^{2 *}$ and Swaranjit Singh Cameotra ${ }^{1}$

${ }^{1}$ IMTECH, Sector 39A, Chandigarh 160036, India

${ }^{2}$ Global Cancer Care, Sector 47, Chandigarh 160047, India,

*Corresponding author: Brijdeep Singh, IMTECH, Sector 39A, Chandigarh 160036, India, Tel: 9041036750; E-mail: brijdeep@gmail.com

Rec date: May 29, 2014, Acc date: May 29, 2014, Pub date: Jun 06, 2014

Copyright: () 2014 Walia NK, et al. This is an open-access article distributed under the terms of the Creative Commons Attribution License, which permits unrestricted use, distribution, and reproduction in any medium, provided the original author and source are credited.

\section{Editorial}

Humanity, in its youth of the third millennium has an astonishing record of material progress, controlling forces of nature, making science and technology the founding fathers of a cultural revolution and transforming the Stone Age into space age. Under conditions of life when there is no conflict a balance between self-interests and environment protection is maintained. Today we are living in a time of stress. In affluent countries the post war period was a prospect of prosperity for everyone, as the fruits of technology were being harvested and nature was exploited thoughtlessly, "Nature is made for man", this was principle for action. Today we are faced with scarcity of resources. We do not know in which direction history will move, but two things are certain, one is that thoughtful people are apprehensive about the future, the other is that this apprehension in some ways changing the social values. Energy is the vital need for mankind The late Nobel laureate Richard Smalley said that "energy is the single greatest challenge facing humanity." Energy can be defined as the ability or the capacity to do work. Energy is used in our day to day life as it lights our cities, powers our vehicles, and runs machinery in factories. In addition, it warms and cools our homes, cooks our food, plays our music, and gives us pictures on television. In recent years, the global demand for energy has been increased massively as a result of industrial development and population growth. However, burning of fossil fuels for the production of energy is thought to be the cause of emissions of carbon dioxide into the Earth's atmosphere which as a result cause rise in global temperatures. The demand for energy, since the early 2000s, especially from liquid fuels, in addition the restrictions on the rate of fuel production have created such a bottleneck leading to the current energy crisis. The next era of constrained and expensive energy will be very difficult for everyone on Earth however; it will be even more difficult if it is not anticipated. So, it is of extreme importance that the public and especially policymakers should understand the global energy crisis and the underlying science.

Electricity generated from fossil fuels such as coal and crude oil has resulted in high concentrations of harmful gases in the atmosphere. This has in turn led to problems such as ozone depletion and global warming. Due to the problems associated with the use of fossil fuels, in today's world, the alternative sources of energy have become important and relevant. One of such sources is the sun. Energy generated from the sun is known as solar energy and is also known as nonconventional source of energy; it causes less emission and is easily available. The solar energy use can significantly reduce chemical, radioactive, and thermal pollution. Sun is a viable source of clean and limitless energy. Solar energy has been used since prehistoric times and it is the most readily available source of energy. Due to the dramatic rise in oil prices in the 1970s, several countries began to formulate extensive research and development programs to exploit solar energy. Solar energy can also be used to meet our electricity requirements. Through Solar Photovoltaic (SPV) cells, solar radiation gets converted into DC electricity directly. This electricity can either be used as it is or can be stored in batteries.

If the means to make efficient use of solar energy could be found, it would reduce our dependence on non-renewable sources of energy and make our environment even cleaner.

Nowadays, bacteria can be employed to produce electric energy. The bio-battery offers an array of advantages due to their simple construction and can be used in regions where there is shortage of electricity especially in developing countries. In the case of biobatteries, the more nourishment the bacteria receive, the more energy they produce. It is interesting to note that bacteria are an inexhaustible source of energy as they multiply quickly when supplied with substrates. There are two ways to convert sun's light in to electricity. Initially, one has to search for a microorganism which can fix carbon dioxide to produce glucose and in addition also fluoresce at night. This will play dual role as it will provide electricity as well as also emits light at night. Further, the biofilm of this kind of microorganisms can be produced. Finally, microbial fuel cells can be attached to these biofilms to convert chemical energy into electrical energy. This process if developed would be very cost-effective. The other method is the utilization of waste which will help in reducing the problem of waste disposal. Microorganisms which produce amylases can be added in rice or corn straw. Further, fermentation cycle for 24-48 hours will produce glucose. The microbial fuel cell battery can be directly attached with the fermentor. Finally, the accumulated glucose can be utilized in microbial fuel cell as a substrate to generate electricity.

This method will be cost effective and an eco-friendly process as microbial biofilms is available in abundance in nature. 